\title{
Complement Activation Problem
}

National Cancer Institute

\section{Source}

National Cancer Institute. Complement Activation Problem. NCI Thesaurus. Code C92035.

The device affects the body's ability to activate the complement system of the immune system, thereby interfering with the ability to clear pathogens. This may be caused by an interaction of the device with chemicals or materials. 